\title{
Large Scale Production and Characterization of Anti-Human IgG Monoclonal Antibody in Peritoneum of Balb/c MICE
}

\author{
${ }^{1}$ B. Baradaran, ${ }^{2}$ J. Majidi, ${ }^{1}$ Z.M. Hassan and ${ }^{2}$ J. Abdolalizadeh \\ ${ }^{1}$ Department of Immunology, Faculty of Medical Sciences, Tarbiat Modarres University, Tehran, Iran \\ ${ }^{2}$ Drug Applied Research Center, Tabriz University of Medical Sciences, Tabriz, Iran
}

\begin{abstract}
Monoclonal antibodies are key reagents that are used in biomedical researches, diagnosis of immunodeficiency diseases such as $\mathrm{IgG}$ subclasses deficiency and treatment of diseases like infections and cancers. For large scale production of monoclonal antibody, hybridoma cells that produce monoclonal antibody against human IgG were injected into the peritoneum of the Balb/c mice which have previously been primed with $0.5 \mathrm{~mL}$ Pristane. After 10 days, approximately $3 \mathrm{~mL}$ ascitic fluid was harvested from the peritoneum of each mouse. Ascitic fluid was assayed for the titer of monoclonal antibody in reaction with human $\mathrm{IgG}$ and its cross reactivity in reaction with $\operatorname{IgM}$ and $\operatorname{IgA}$. The titer of mAb was 100,000 and didn't show cross reactivity with IgM and IgA. Immunobloting was done for confirming the ELISA method. In immunobloting, only one sharp band in the heavy chain position of IgG was developed. The subclass of antibody was IgG1 and its light chain was kappa. Ascitic fluid was purified by ion exchange chromatography and the purified monoclonal antibody was conjugated with HRP. The conjugated monoclonal antibody could had application in diagnosis of infectious diseases like Toxoplasmosis, Rubella and $\mathrm{IgG}$ class of all other infectious diseases.
\end{abstract}

Key words: Monoclonal antibody, ascetic fluid, human IgG

\section{INTRODUCTION}

Monoclonal antibodies (mAbs) are important tools used in biomedical researches, diagnosis and treatment of the diseases like infectious diseases and cancers ${ }^{[1,2]}$. In most diagnostic kits of the infectious diseases like Toxoplasmosis, Rubella and Cytomegalovirus, monoclonal antibodies against human IgG conjugated with enzymes, fluorochromes or radioactive labels fulfill a key role. Monoclonal antibodies were produced for the first time by Milstein and Kohler ${ }^{[3]}$. These antibodies are mainly produced by clones or cell lines of Balb/c mice immunized with the requested immunogens. For large scale production of the monoclonal antibody, hybridoma cells should be reproduced by one of the flowing methods:

- Injection of requested clone into the peritoneum of the mouse that has previously been primed with Pristane ${ }^{[4]}$

- Culture of the cells in tissue culture flasks

When hybridoma cells are injected into the peritoneum of mouse, the cells grow and produce ascitic fluid. This fluid has high concentration of antibody. The method of ascitic fluid production in peritoneum of mouse is simple and economic ${ }^{[5]}$. But reproduction of cells in cell culture media needs special skills, special medium and FCS that is expensive and an idling technique ${ }^{[6]}$. Furthermore, the loss of antibody's original glycosilation by in vitro culture method makes it unsuitable for long time functions. So, antibody production in ascitic fluid can be a suitable and economical method.

\section{MATERIALS AND METHODS}

The six 4-6 weeks old Balb/c mice were provided from the Razi Institute (Tehran, Iran). $0.5 \mathrm{~mL}$ Pristane (2, 6, 10, 14 tetramethylpentadecane, Sigma) was injected intraperitoneally into each mouse. Ten days after priming with Pristane, the cells of a suitable mono clone in density of $10^{6}$ cells $/ 0.5 \mathrm{~mL}$ PBS were injected intraperitoneally into each mouse ${ }^{[7]}$. Five days after the injection of hybridoma cells, the mice were assessed daily for production of ascitic fluid. About ten days after the injection of cells, abdomen of the mice were completely enlarged and their skins were extended. Using 19 gage needles, their ascitic fluids were harvested. After 4 days, ascitic fluid of the mice were harvested again and centrifuged and the related supernatants were collected for characterization.

Determining the antibody titer and its cross reactivity with $\operatorname{IgM}$ and $\operatorname{IgA}$.

The titer of monoclonal antibody was assessed by ELISA method. In this assay, first human IgG $(5 \mu \mathrm{g}$ $\mathrm{mL}^{-1}$ ) was coated for 45 minutes in 96 wells plate (Nunc). After twice washing with PBS-Tween 20 $(0.05 \%)$, non specific sites were blocked with $2 \%$ BSA and incubated at $37^{\circ} \mathrm{C}$ for $45 \mathrm{~min}$. The washing was

Corresponding Author: B. Baradaran, Department of Immunology, Faculty of Medical Sciences, Tarbiat Modarres University, Tehran, Iran Tel: +98 4113806685 Fax: +98 4113352597 
repeated and then $100 \mu \mathrm{L}$ of the continuous dilution of ascitic fluid was added to each well and incubated for $1 \mathrm{~h}$ at $37^{\circ} \mathrm{C}$. Then the plate was washed 5 times. $100 \mu \mathrm{L}$ of Rabbit Anti-mouse IgG conjugate with 1/4000 dilution (Sigma) was added to each well and incubated for $45 \mathrm{~min}$ at $37^{\circ} \mathrm{C}$. After five times of washing, $100 \mu \mathrm{L}$ of TMB substrate solution (Sigma) was added into each well and incubated for $15 \mathrm{~min}$ in dark place at $37^{\circ} \mathrm{C}$. The reaction was stopped by $100 \mu \mathrm{L}$ of $5 \%$ solution of Sulfuric Acid. The absorbance of each well was read by ELISA Reader at $450 \mathrm{~nm}$ and therefore the titer of monoclonal antibody in ascitic fluid was determined ${ }^{[8]}$.

In order to determine the cross reactivity with IgM and $\operatorname{IgA}$, the micro titer plates were coated with each class of the purified immunoglobulins $\left(5 \mu \mathrm{g} \mathrm{mL}^{-1}\right.$ in coating buffer, $100 \mu \mathrm{L} /$ well) and incubated for $1 \mathrm{~h}$ at $37^{\circ} \mathrm{C}$. The plates were blocked with $2 \%$ BSA as described above. Following a soak and wash cycle, the ascitic fluid with distinct dilution was added to the wells and incubated as described above. The rest of the assay was preceded as described for the ELISA procedure. In the end of the reaction and by reading their absorbance, cross reactivity of the monoclonal antibodies with $\operatorname{IgM}$ and $\operatorname{IgA}$ was determined.

Immunoblotting: This technique was used for confirming the result of cross reactivity with $\operatorname{IgM}$ and IgA by ELISA method. First, the nitrocellulose membrane and several thicknesses of Whatman chromatography paper were soaked in the transfer buffer (25 mM Tris, $192 \mathrm{mM}$ glycine, 20\%V/V methanol, $\mathrm{pH} 8.3$ ). The wet nitrocellulose membrane was overlaid on the wet Whatman sheets by taking precaution to avoid bubbles. Then, the gel of SDSPAGE was placed on the wet nitrocellulose membrane and then several wet Whatman papers were placed on it. Transfer of the proteins from gel to nitrocellulose membrane was done in $100 \mathrm{~V}$ for $3 \mathrm{~h}$. Then, non specific sites were blocked with $2 \%$ BSA solution. After three times of washing, the membrane was cut into strips and incubated for $2 \mathrm{~h}$ at $37^{\circ} \mathrm{C}$ using the ascitic fluid. Again, after five times of washing, the strips were incubated for $2 \mathrm{~h}$ at $37^{\circ} \mathrm{C}$ with Rabbit AntiMouse IgG conjugate (1/2000 dilution). The strips were washed and then developed in DAB substrate (Sigma). The sharp band was appeared in its molecular weight position $^{[9]}$.

Isotyping: The class and subclasses of the mAbs were determined by an enzyme immunoassay employing a mouse-hybridoma sub typing kit (ZYMED). After coating the human IgG to each well, ascitic fluid with distinct dilution was added. After washing process, Rabbit Anti-Mouse classes or subtypes of light and heavy chains were added. After adding the HRP conjugated Goat Anti-Rabbit IgG and specific substrate (TMB), the developed color, due to the reaction of enzyme and substrate, was read at $405 \mathrm{~nm}^{[10]}$.
Purification: The ascitic fluids were diluted 1-2 with PBS and fractionated with $40 \%$ saturated ammonium sulfate. After several times of washing with $40 \%$ ammonium sulfate, the fraction was centrifuged for $15 \mathrm{~min}$ in $5000 \mathrm{~g}$. The precipitated fraction was dialyzed against $0.05 \mathrm{M}$ phosphate buffer $\mathrm{pH} 7.4$ containing $0.05 \mathrm{M} \mathrm{Nacl}$. The final dialyze was exchanged against the column washing buffer (Tris $40 \mathrm{mM}$ ). Purification of ascitic fluid was done by Ion exchange chromatography (DEAE-Sepharose 6B) which is a simple and economical method ${ }^{[9]}$. At first, the column was eluted with washing buffer (Tris $40 \mathrm{mM}, \mathrm{pH} \mathrm{8.1)}$ in order that the $\mathrm{pH}$ of the external buffer to be the same as the PH of internal buffer. Then the dialyzed sample in $60 \mathrm{mg} / 3 \mathrm{~mL}$ concentration was run to the column with dimensions of $1.6 \times 15 \mathrm{~cm}$. Distinct antibody was eluted from the column through washing buffer containing $50 \mathrm{mM} \mathrm{Nacl}$ and the fractions were collected in $5 \mathrm{~mL} / 20^{\prime}$. Confirmation of the purified fractions was done by SDS-PAGE in reducing condition. Finally, the purified fractions were kept for conjugation with Peroxidase.

Conjugation of monoclonal antibody with Horseradish Peroxidase enzyme (HRP): For conjugation, the Nakan and Periodate methods were used $^{[11]}$. First, $4 \mathrm{mg}$ of HRP was dissolved in $1 \mathrm{~mL}$ of distillated water. Then $0.2 \mathrm{~mL}$ freshly prepared sodium Periodate solution $(0.1 \mathrm{M})$ was added to the enzymatic solution and incubated on shaker for, $20 \mathrm{~min}$ at room temperature. The solution was dialyzed against acetate buffer ( $\mathrm{pH} 4.4$ ), over night at $4^{\circ} \mathrm{C}$. About $8 \mathrm{mg}$ of the purified monoclonal antibody was dissolved in $1 \mathrm{~mL}$ sodium carbonate $(10 \mathrm{mM}, \mathrm{pH}$ 9.5).The $\mathrm{pH}$ of the dialyzed enzyme was reached to 9 and immediately the solution containing monoclonal antibody was added to it and shacked for $2 \mathrm{~h}$ at room temperature. Then $0.1 \mathrm{~mL}$ of the freshly prepared sodium brohydrate was added and incubated for $30 \mathrm{~min}$ at room temperature. The final solution was precipitated with ammonium sulfate and then was dialyzed against PBS buffer.

\section{RESULTS}

After priming the peritoneum of the mice with Pristane, $1 \times 10^{6}$ cells related to the suitable mono clone (Fig. 1) were suspended in $0.5 \mathrm{~mL}$ of sterile PBS and injected to each mouse. Ten day later, about $3 \mathrm{~mL}$ ascitic fluids rich with a suitable mAb was harvested from each mouse. Again, after 4 days, about 2-3 mL ascitic fluid was harvested from their peritoneum. The titer of monoclonal antibody in ascitic fluid was assessed by ELISA method. Absorbance (OD) of $1 / 100,000$ dilution was above 1 . With the same titer, the suitable mAb didn't show any cross reactivity in reaction with $\operatorname{IgM}$ and $\operatorname{IgA}$ (Table 1). Immunoblotting was done for confirming the results of ELISA method. The result of Iimmunoblotting showed that the produced antibody was against IgG heavy chain. 


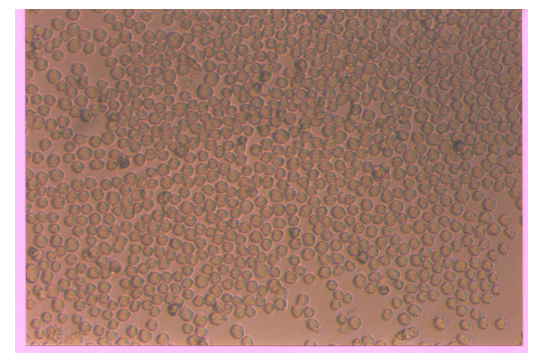

Fig 1: Proliferated suitable mono clone (Mag.10X) selected for injection into the peritoneum of mice

Table 1: Comparison of the mean absorbance and cross reactivity of ascitic fluid at $450 \mathrm{~nm}$

\begin{tabular}{lccc}
\hline & IgG & IgM & IgA \\
\hline Sp2/0(N.C) & 0.06 & 0.05 & 0.06 \\
Mouse serum (N.C)* & 0.12 & 0.09 & 0.11 \\
Immune mouse serum (P.C)** & 1.00 & 0.13 & 0.12 \\
Ascitic fluid (1/100000 dilution) & 1.14 & 0.07 & 0.06 \\
\hline *: Negative control with 1/8000 dilution; **: Positive control with \\
1/8000 dilution
\end{tabular}

Table 2: Comparison of the mean absorbance of mouse anti-human IgG conjugate at $450 \mathrm{~nm}$

\begin{tabular}{llll}
\hline & $\mathrm{IgG}$ & $\mathrm{IgM}$ & $\mathrm{IgA}$ \\
\hline Sp2/0(N.C) & 0.09 & 0.06 & 0.04 \\
$\begin{array}{l}\text { Mouse anti-human } \\
\text { IgG conjugate* }\end{array}$ & 1.32 & 0.04 & 0.05 \\
\hline$* \cdot 1 / 64,000$ dilution & & &
\end{tabular}

*: 1/64,000 dilution

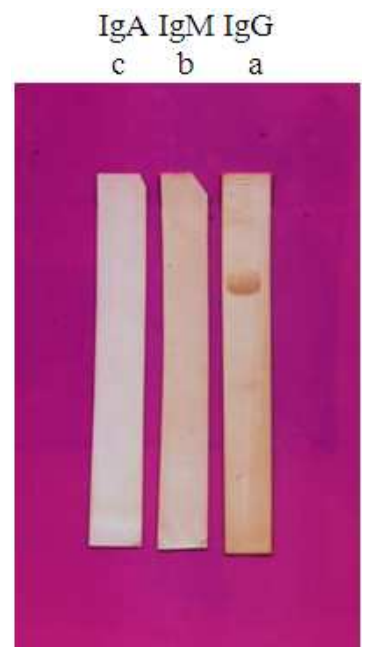

Fig 2: The immunobloting of ascitic fluid related to suitable mono clone (at 1/10000 dilution) (a) high density band in $50 \mathrm{KD}$ position is related to the reaction of suitable mab with purified IgG (b and c) showing no band at any position is related to the free of cross reactivity of suitable mab in reaction with $\operatorname{IgM}$ and $\operatorname{Ig} \mathrm{A}$

This antibody didn't show cross reactivity with the light and heavy chains of $\operatorname{IgM}$ and $\operatorname{IgA}$ and a sharp band was only appreared in IgG heavy chain position (Fig. 2). The ascitic fluid was examined for class and subclasses by mouse isotyping kit (ZYMED). The subclass of monoclonal antibody was IgG1 and its light chain was "kappa" type (Table 2).

The diluted ascitic fluid was precipitated with saturated ammonium sulfate and dialyzed against PBS $\mathrm{pH}$ 7.4. Concentration of the dialyzed product in assay with UV at $280 \mathrm{~nm}$ was about $100 \mathrm{mg}$. Its purification with ion exchange chromatography yielded about $30 \mathrm{mg}$ of purified monoclonal antibody. The purified monoclonal antibody was conjugated with peroxidase. The titer of conjugate was 100,000 and didn't show any cross reactivity with $\operatorname{IgM}$ and $\operatorname{IgA}$.

\section{DISCUSSION}

Antibodies are extraordinarily useful molecules. Their highly specific binding to wide ranges of molecules and their ability to identify specific antigenic determinants in these molecules make them extremely valuable adjuncts to biomedical researches. On the other hand monoclonal antibodies have many applications in diagnosis, treatment and purification. In most infectious diseases, especially in chronic condition, the class of the produced antibody against pathogen is IgG. Therefore monoclonal anti-human IgG conjugate is very important and as a key reagent for its recognition ${ }^{[1,11]}$. So, production of monoclonal antibody without any cross reactivity with homologous molecules such as $\operatorname{IgM}$ and $\operatorname{IgA}$ can be used in diagnostic kits of infectious diseases. The production of monoclonal antibody in the ascitic fluid is commercially useful for mass production. Ascitic fluid production enriched with $\mathrm{mAb}$ in mice is a rapid and economic method ${ }^{[5]}$. The amount of the injected Pristane and the interval of priming with hybridoma cells are very important factors in ascitic fluid production. Also the number of the cells injected to the peritoneum of mouse is highly effective on the acceleration of ascitic fluid production. One million cells injected to the peritoneum of mouse could enable the harvest of about 3-4 mL ascitic fluid from the peritoneum of each mouse. Since several liters of RPMI medium and FCS as well as several months of continue struggle and attention are needed for the production of this amount of antibody by in vitro method. Therefore, it seems that ascitic fluid production method is a very useful and economic method.

\section{REFERENCES}

1. Ben, K.S., 1996. Monoclonal antibody reactive to human leukemia and lymphoma cells and methods of using same for diagnosis and treatment. Biotechnol. Adv., 14: 583-583.

2. Graciela, G., C.H. Mordhorst and C. Koch, 1995. Monoclonal antibodies for the direct detection of influenza-a virus by ELISA in clinical specimens from patients with respiratory infections. Clin. Diagn. Virol., 3: 361-369. 
3. Kohler, G. and C. Milstein, 1975. Continuous cultures of fused cells secreting antibody of predefined specificity. Nature, 256: 495-497.

4. Jackson, L.R., L.J. Trudel, J.G. Fox and N.S. Lipman, 1999. Monoclonal antibody production in murine ascites. I. Clinical and pathologic features. Lab. Anim. Sci., 49: 70-80.

5. McArdle, J., 1998. Alternatives to ascites production of monoclonal antibodies. Anm. Welfare Inform. Center Newslett., 8: 3-4.

6. Lang, A.B., U. Schuerch and S.J.Jr. Cryz, 1991. Optimization of growth and secretion of human monoclonal antibodies by hybridomas cultured in serum-free media. Hybridoma, 10: 401-409.

7. Jackson, L.R., L.J. Trudel, J.G. Fox and N.S. Lipman, 1999. Monoclonal antibody production in murine ascites. II. Production characteristics. Lab. Anim. Sci., 49: 81-86.

8. Paul, D.F., N. Misawa, G. Sandmann, J. Johnson, W. Schuch and P.M. Bramley, 1998. Production and characterisation of monoclonal antibodies to phytoene synthase of Lycopersicon esculentum. Phytochemistry, 49: 971-978.
9. Ming, G., B. Su, C. Ye and Y. Lu, 2002. Production of extracellular domain of human tissue factor using maltose-binding protein fusion system. Protein Express. Purificat., 26: 229-234.

10. Girish, C.D., C.C. Bergstrom, G.A. Andrews and S. Kapil, 1999. Production, characterization and uses of monoclonal antibodies against recombinant nucleoprotein of elk coronavirus. Clin. Diagn. Lab. Immun., 6: 341-344.

11. Yücel, F., M. Aliihsan and B.A. Aynur, 2003. Production and characterization of monoclonal antibodies against hepatitis B viruses and application of a quick sandwich ELISA. Hybrid. Hybridom., 22: 173-177. 